\title{
Colorimetric Quantification Methods for Peracetic Acid together with Hydrogen Peroxide for Water Disinfection Process Control
}

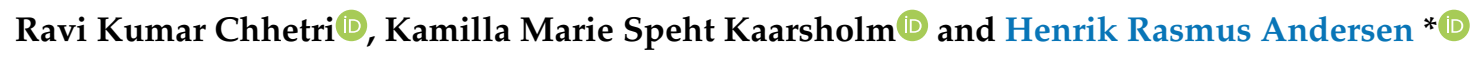 \\ Department of Environmental Engineering, Technical University of Denmark, 2800 Kgs. Lyngby, Denmark; \\ rakc@env.dtu.dk (R.K.C.); kmsh@env.dtu.dk (K.M.S.K.) \\ * Correspondence: henrik@ndersen.net
}

Received: 11 May 2020; Accepted: 22 June 2020; Published: 28 June 2020

\begin{abstract}
Peracetic acid (PAA) water solutions is applied for disinfection of industry systems, food products and non-potable water. Commercially available peracetic acid is always supplied mixed with hydrogen peroxide $\left(\mathrm{H}_{2} \mathrm{O}_{2}\right) \cdot \mathrm{H}_{2} \mathrm{O}_{2}$ degrade slower than the peracetic acid which creates a need to quantify both peroxides separately to gauge the disinfection power of the solution and the residuals. Two combinations of colorimetric reactions are presented that allows simultaneous quantification at the $\mathrm{mg} \cdot \mathrm{L}^{-1}$ level used in disinfection liquids and water disinfection. The first dichromic reaction use titanium oxide oxalate (TiO-Ox) which only react with $\mathrm{H}_{2} \mathrm{O}_{2}$ followed by addition of $\mathrm{N}, \mathrm{N}$-diethyl-p-phenylenediamine with iodide $\left(\mathrm{DPD} / \mathrm{I}^{-}\right)$and the concentrations are read by simultaneously measuring the absorbance at 400 and $515 \mathrm{~nm}$. Limit of quantification (LOQ) and maximal concentration determined was $4.6 \mu \mathrm{g} \cdot \mathrm{L}^{-1}$ and $2.5 \mathrm{mg} \cdot \mathrm{L}^{-1}$ for PAA and $9.1 \mu \mathrm{g} \cdot \mathrm{L}^{-1}$ and $5 \mathrm{mg} \cdot \mathrm{L}^{-1}$ for $\mathrm{H}_{2} \mathrm{O}_{2}$. The two color reactions didn't interfere with each other when the reagent addition was consecutive. Another combination of colorimetric reaction also used where TiO-Ox was used to first measure $\mathrm{H}_{2} \mathrm{O}_{2}$ at $400 \mathrm{~nm}$, before addition of 2,2'-azino-bis(3-ethylbenzothiazoline-6-sulphonic acid (ABTS)) and reading the absorbance at $405 \mathrm{~nm}$. ABTS changes the absorbance at $405 \mathrm{~nm}$ necessitating the two measurements be done separately. LOQ and maximal concentration determined using ABTS colorimetric assay was $42.5 \mu \mathrm{g} \cdot \mathrm{L}^{-1}$ and $30 \mathrm{mg} \cdot \mathrm{L}^{-1}$ for PAA and for titanium oxide oxalate colorimetric assay was $12.7 \mu \mathrm{g} \cdot \mathrm{L}^{-1}$ and $75 \mathrm{mg} \cdot \mathrm{L}^{-1}$ for $\mathrm{H}_{2} \mathrm{O}_{2}$. Both methods tested satisfactory in typical water samples (Tap, sea, lake, and biological treated sewage) spiked with peracetic acid and $\mathrm{H}_{2} \mathrm{O}_{2}$, separately.
\end{abstract}

Keywords: peracetic acid; 2,2'-azino-bis(3-ethylbenzothiazoline-6-sulphonic acid (ABTS); N,Ndiethyl-p-phenylenediamine (DPD); disinfection; hydrogen peroxide

\section{Introduction}

Disinfection is necessary to prohibit the spread of diseases and limiting the number of pathogenic organisms in the water industry. Various well known disinfectants are currently used in the water industry such as hypochlorite and chlorine dioxide [1], which could be used to reduce contamination by microorganisms. However, the toxic by-products of these compounds are of environmental concern [1-9]. Alternatively, peroxycarboxylic acids such as peracetic acid (PAA) has been used for disinfection. Furthermore, they do not generate toxic by-products $[10,11]$. Commercially available peroxycarboxylic acids are always available as a mixture of peroxycarboxylic acids, hydrogen peroxide $\left(\mathrm{H}_{2} \mathrm{O}_{2}\right)$ and carboxylic acids.

PAA is a strong disinfectant with a wide spectrum of antimicrobial activity which was introduced to wastewater treatment approximately 30 years ago [12-17] and recently has been used to disinfect 
combined sewer overflows [11,18]. Commercial PAA is available as an acidic quaternary equilibrium mixture of PAA, $\mathrm{H}_{2} \mathrm{O}_{2}$, acetic acid, and water:

$$
\mathrm{CH}_{3} \mathrm{COOH}+\mathrm{H}_{2} \mathrm{O}_{2} \rightleftharpoons \mathrm{CH}_{3} \mathrm{CO}_{3} \mathrm{H}+\mathrm{H}_{2} \mathrm{O}
$$

The residues after PAA use are acetic acid, $\mathrm{H}_{2} \mathrm{O}_{2}$, and water. Hydrogen peroxide tend to degrade slower than peroxycarboxylic acids [19] and it has a stringent discharge limit in relation to surface water.

To control the disinfection process, it is important to measure the exact concentration of disinfectant. The measured concentration of disinfectant is used to calculate and correlate the removal of microorganisms from disinfection process. Therefore, it is important to measure the residual concentration of both peroxycarboxylic acids and $\mathrm{H}_{2} \mathrm{O}_{2}$ when it is applied in the full scale disinfection and before it is discharged to the surface water to limit the adverse effect on aquatic life.

Among various colorimetric assay, $\mathrm{N}, \mathrm{N}$-diethyl-p-phenylenediamine (DPD) with iodide (DPD/I ${ }^{-}$ colorimetric assay $[13,20,21]$ and ABTS (2,2'-azino-bis(3-ethylbenzothiazoline-6-sulphonic acid)) colorimetric assay [11,22], has been widely used for quantification of peroxycarboxylic acids and $\mathrm{H}_{2} \mathrm{O}_{2}$ using different reaction condition and reagents. Titanium oxide oxalate (TiO-Ox) color assay has been used for quantification of $\mathrm{H}_{2} \mathrm{O}_{2}$ [23]. Wagner et al., [19] have used ABTS colorimetric assay to measure concentration of PAA and $\mathrm{H}_{2} \mathrm{O}_{2}$ by measuring the concentration of total peroxycarboxylic acid and subtracting the concentration of $\mathrm{H}_{2} \mathrm{O}_{2}$ from the total peroxycarboxylic acid concentration. Similarly, Pedersen et al., [20] have used DPD colorimetric assay to measure peracetic acid and $\mathrm{H}_{2} \mathrm{O}_{2}$ separately using different reaction conditions and combining peroxidase enzyme. Domínguez-Henao et al., [24] have used two methods using DPD, iodine and ammonium molybdate as catalysis to determine PAA and total peroxide (PAA $+\mathrm{H}_{2} \mathrm{O}_{2}$ ). As of our knowledge, colorimetric assay that can simultaneously quantify peroxycarboxylic acids and $\mathrm{H}_{2} \mathrm{O}_{2}$ is not available. However, it is necessary when peroxycarboxylic acid is used for full-scale disinfection to control the dosing of peroxycarboxylic acid and discharge of residual peroxycarboxylic acid and $\mathrm{H}_{2} \mathrm{O}_{2}$.

Therefore, the objective of this study was to develop a colorimetric assay which can quantify the peroxycarboxylic acids and $\mathrm{H}_{2} \mathrm{O}_{2}$ simultaneously. To do that, two combinations of two colorimetric assays TiO-Ox:DPD $/ \mathrm{I}^{-}$and TiO-Ox:ABTS were used.

\section{Materials and Methods}

\subsection{Chemicals}

All chemicals, unless stated otherwise, were purchased from Sigma-Aldrich (Brøndby, Denmark) and were of reagent grade. From peracetic acid (PAA) solution (30-40\% $w / w$ PAA and $5 \% w / w \mathrm{H}_{2} \mathrm{O}_{2}$ of technical grade disinfectant), a working solution of $1 \mathrm{~g} \cdot \mathrm{L}^{-1}$ PAA was made, which was quantified daily by iodometric titration described below in Section 2.2. All solution were prepared in ultrapure water.

\subsection{Sample Preparation and Analysis}

Reaction time and reagents volume for color assay was optimized by measuring absorption spectra from $300 \mathrm{~nm}$ to $800 \mathrm{~nm}$. A wavelength with high absorbance (peak) was selected from absorption spectra of oxidized TiO-Ox, DPD and ABTS to quantify $\mathrm{H}_{2} \mathrm{O}_{2}$ and PAA.

\subsubsection{ABTS Colorimetric Assay}

Standard solution of peroxycarboxylic acid, $\mathrm{H}_{2} \mathrm{O}_{2}$ and samples were prepared in volumetric flasks. After dilution of the PAA stock solution to the concentration range from $0.5 \mathrm{mg} \cdot \mathrm{L}^{-1}$ to $100 \mathrm{mg} \cdot \mathrm{L}^{-1}$ in ultrapure water, $350 \mu \mathrm{L}$ sample, $350 \mu \mathrm{L}$ of $1 \mathrm{M}$ acetic acid (AA, pH 3.5) and $350 \mu \mathrm{L}$ of ABTS $\left(1 \mathrm{~g} \cdot \mathrm{L}^{-1}\right.$ in ultrapure water) were added and color was allowed to develop for $10 \mathrm{~min}$. The reaction products was observed photometrically at $405 \mathrm{~nm}$ in a $1.0 \mathrm{~cm}$ polypropylene cuvette [11]. Varian Cary $200 \mathrm{UV}-\mathrm{Vis}$ photometer was used to measure the absorbance. 


\subsubsection{DPD/Iodide Colorimetric Assay}

The DPD (N,N-dimethyl-p- phenylenediamine) color reagent was used to quantify PAA. The DPD reagent was prepared by mixing $70 \mathrm{mg}$ EDTA and $385 \mathrm{mg}$ DPD in $100 \mathrm{~mL}$ ultrapure water acidified by adding $25 \mathrm{~mL}$ of $0.5 \mathrm{M}$ sulfuric acid. Dilution of the PAA stock solution to the concentration range from $0.125 \mathrm{mg} \cdot \mathrm{L}^{-1}$ to $3 \mathrm{mg} \cdot \mathrm{L}^{-1}$ in ultrapure water was measured by adding $7 \mathrm{~mL}$ of sample, $100 \mu \mathrm{L}$ $\mathrm{AA}(1 \mathrm{M}, \mathrm{pH} 5), 100 \mu \mathrm{L} \mathrm{KI}\left(70 \mathrm{~g} \cdot \mathrm{L}^{-1}\right.$ in ultrapure water) and $100 \mu \mathrm{L}$ DPD reagents in a glass beaker. After $1 \mathrm{~min}$ of reaction time, the reaction product was observed photometrically at $515 \mathrm{~nm}$ in a $1.0 \mathrm{~cm}$ polypropylene cuvette.

\subsubsection{TiO-Ox Colorimetric Assay}

$\mathrm{H}_{2} \mathrm{O}_{2}$ from sample was measured photometrically at $400 \mathrm{~nm}$ by adding $2 \mathrm{~mL}$ sample and $0.2 \mathrm{~mL}$ of potassium titanium oxide oxalate $\left(50 \mathrm{~g} \cdot \mathrm{L}^{-1}\right)$ in a $1.0 \mathrm{~cm}$ polypropylene cuvette after 1 min reaction time.

\subsubsection{TiO-Ox:DPD/I- Colorimetric Assay}

PAA and $\mathrm{H}_{2} \mathrm{O}_{2}$ from sample were measured photometrically by adding $3.5 \mathrm{~mL}$ sample, $0.350 \mathrm{~mL}$ of potassium titanium oxide oxalate $\left(50 \mathrm{~g} \cdot \mathrm{L}^{-1}\right), 50 \mu \mathrm{L}$ AA $(1 \mathrm{M}, \mathrm{pH}$ ) $), 50 \mu \mathrm{L} \mathrm{KI}\left(70 \mathrm{~g} \cdot \mathrm{L}^{-1}\right.$ in ultrapure water) and $50 \mu \mathrm{L}$ DPD reagents in a glass beaker. After $1 \mathrm{~min}$ of reaction time, the reaction product was observed photometrically at $400 \mathrm{~nm}$ for $\mathrm{H}_{2} \mathrm{O}_{2}$ and $515 \mathrm{~nm}$ for PAA in a $1.0 \mathrm{~cm}$ polypropylene cuvette.

\subsubsection{Samples}

Secondary treated wastewater effluent was collected from Lundtofte WWTP, Denmark. Sea water was collected from Øresund Sea, lake water was collected from Gentofte Lake and non-chlorinated tap water. Samples were spiked with different concentration of PAA and concentration of PAA were quantified using TiO-Ox and DPD/ $/ \mathrm{I}^{-}$and TiO-Ox and ABTS color assay described above.

\subsubsection{Iodometric Titration}

The two step titration was used to determine the $\mathrm{H}_{2} \mathrm{O}_{2}$ and peroxycarboxyclic acid based on the procedures described originally by [25]: a 100-200 mg of samples was accurately weighed into the titration vessel containing $10 \mathrm{~mL}$ of $5 \% \mathrm{H}_{2} \mathrm{SO}_{4}$ solution. One piece of ice was added to maintain the temperature of the aliquot solution under $10{ }^{\circ} \mathrm{C}$. An amount of $40 \mathrm{~mL} \mathrm{H}_{2} \mathrm{SO}_{4}$ solution and 3 drops of ferroin indicator were added and the sample was titrated with $0.1 \mathrm{~N}$ ammonium cerium sulphate solution from orange to light blue. To determine the peroxycarboxylic acids concentration, $5 \mathrm{~mL}$ of the $10 \% \mathrm{KI}$ solution, 3 drops of the ammonium heptamolybdate solution and $1 \mathrm{~mL}$ of the starch solution were added in the aliquot solution from which $\mathrm{H}_{2} \mathrm{O}_{2}$ was titrated. The liberated iodine was titrated with $0.1 \mathrm{~N} \mathrm{Na}_{2} \mathrm{~S}_{2} \mathrm{O}_{3}$ solution from dark brown color to orange. The concentration of $\mathrm{H}_{2} \mathrm{O}_{2}$ and PAA determined from titration was used to measure the dilution of the $\mathrm{PAA}$ and $\mathrm{H}_{2} \mathrm{O}_{2}$ stock solution for colorimetric assay.

\subsection{Limit of Detection and Quantification of Analytical Methods}

The calibration curve was acquired by linear regression analysis. Blank and lowest concentration was measured in a seven replicate to measure the limit of detection (LOD) and the limit of quantification (LOQ). The LOD was calculated as 3 times the standard deviation of the blank and the LOQ as 10 times of the standard deviation of the blank. Sample absorbance was corrected for reagent blanks and concentrations calculated using a standard curve slope. The tested concentration ranges were (i) for DPD/I- PAA $0.125-10 \mathrm{mg} \cdot \mathrm{L}^{-1} \mathrm{PAA}$, (ii) for ABTS $0.125-50 \mathrm{mg} \cdot \mathrm{L}^{-1} \mathrm{PAA}$, and (iii) for TiO-Ox $0.025-100 \mathrm{mg} \cdot \mathrm{L}^{-1} \mathrm{H}_{2} \mathrm{O}_{2}$, (iv) for TiO-Ox:DPD/I- $0.125-5 \mathrm{mg} \cdot \mathrm{L}^{-1} \mathrm{H}_{2} \mathrm{O}_{2}$ and $0.125-10 \mathrm{mg} \cdot \mathrm{L}^{-1}$ PAA. 


\section{Results and Discussion}

\subsection{Principle}

DPD reagent together with potassium iodide is widely used to quantify chlorine species, PAA and $\mathrm{H}_{2} \mathrm{O}_{2}$ in water samples from different sources $[1,20]$. The purposed colorimetric assay (Method 1) with DPD/ $\mathrm{I}^{-}$and titanium oxide oxalate measures the concentration of both peroxycarboxylic acid and $\mathrm{H}_{2} \mathrm{O}_{2}$ in single step at two different wavelengths which makes it easy to quantify both PAA and $\mathrm{H}_{2} \mathrm{O}_{2}$ together without interference from each other.

ABTS colorimetric assay was used together with TiO-Ox to quantify the PAA and $\mathrm{H}_{2} \mathrm{O}_{2}$ in two steps (Method 2). In the first step, $\mathrm{TiO}-\mathrm{Ox}$ react with $\mathrm{H}_{2} \mathrm{O}_{2}$ that is present in PAA to make a complex compounds which can quantified at $400 \mathrm{~nm}$ whilst in Step 2, PAA can oxidize colorless ABTS to green color $\mathrm{ABTS}^{\bullet+}$ which can quantified spectrophotometrically at $405 \mathrm{~nm}$ (Figure 1).
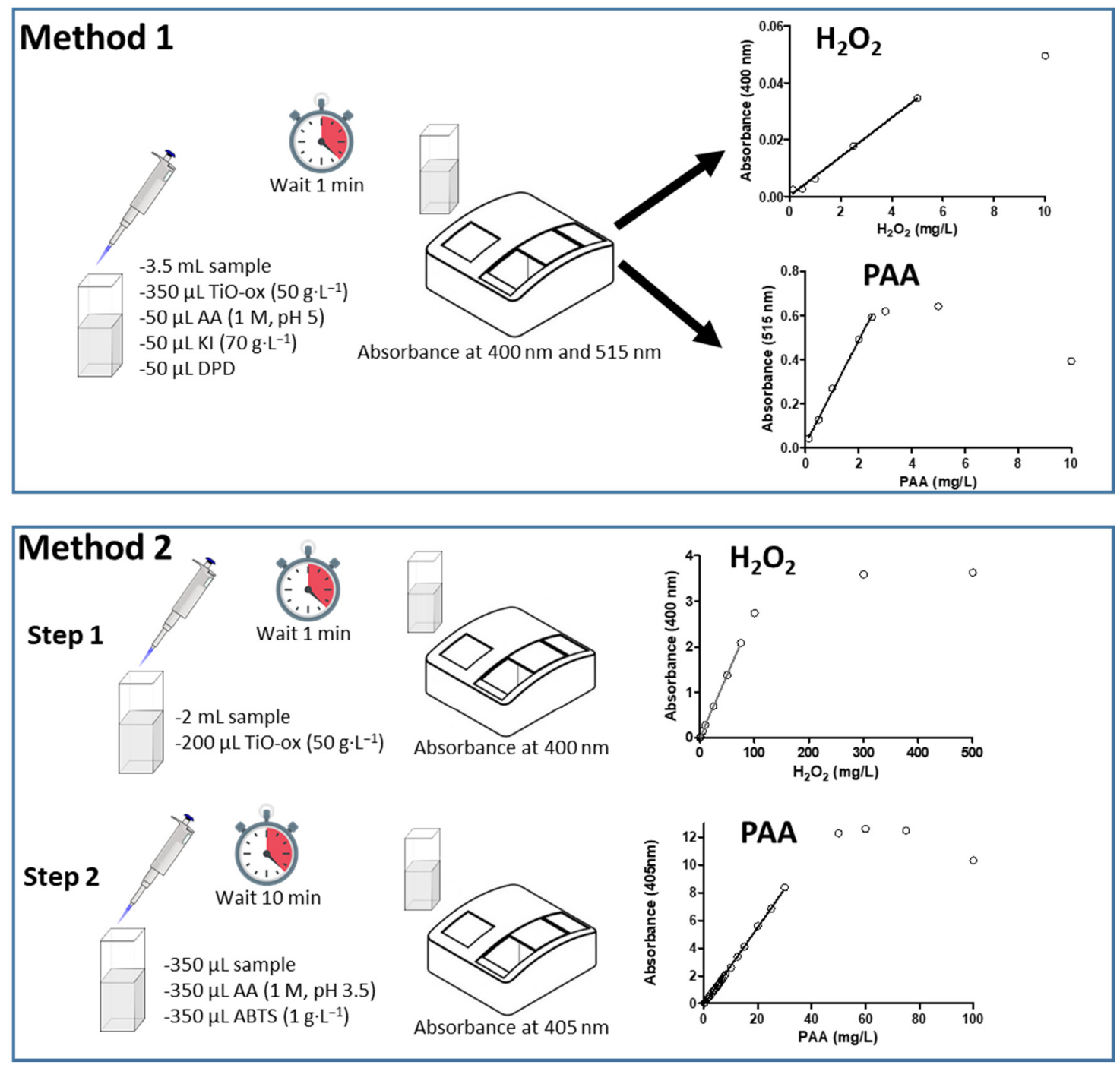

Figure 1. Schematic diagram showing the steps of the two methods used for quantification of peracetic acid (PAA) and hydrogen peroxide $\left(\mathrm{H}_{2} \mathrm{O}_{2}\right)$ : (TiO-Ox: titanium oxide oxalate; AA: Acetic acid; KI: potassium iodide; DPD: N,N-dimethyl-p-phenylenediamine; ABTS: 2,2'-azino-bis (3-ethylbenzothiazoline-6-sulphonic acid). 


\subsection{Selectivity of Colorimetric Reactions}

\subsubsection{Hydrogen Peroxide Reaction with TiO-Ox, DPD and ABTS}

Reagents used in $\mathrm{DPD} / \mathrm{I}^{-}, \mathrm{ABTS}$ and $\mathrm{TiO}-\mathrm{O} x$ colorimetric assay were mixed with ultrapure water and absorption spectra were measured in the same condition as it was measured for colorimetric assay of ABTS and DPD/ $\mathrm{I}^{-}$mentioned in Section 2.2. This was done to check the cross reaction of reagents itself without adding oxidants. It was observed that reagents; $\mathrm{DPD} / \mathrm{I}^{-}$and $\mathrm{TiO}-\mathrm{Ox}$ or $\mathrm{ABTS}$ and $\mathrm{TiO}-\mathrm{Ox}$ does not react to each other and does not develop the color which can be quantified spectrophotometrically (Figure 2A,B).
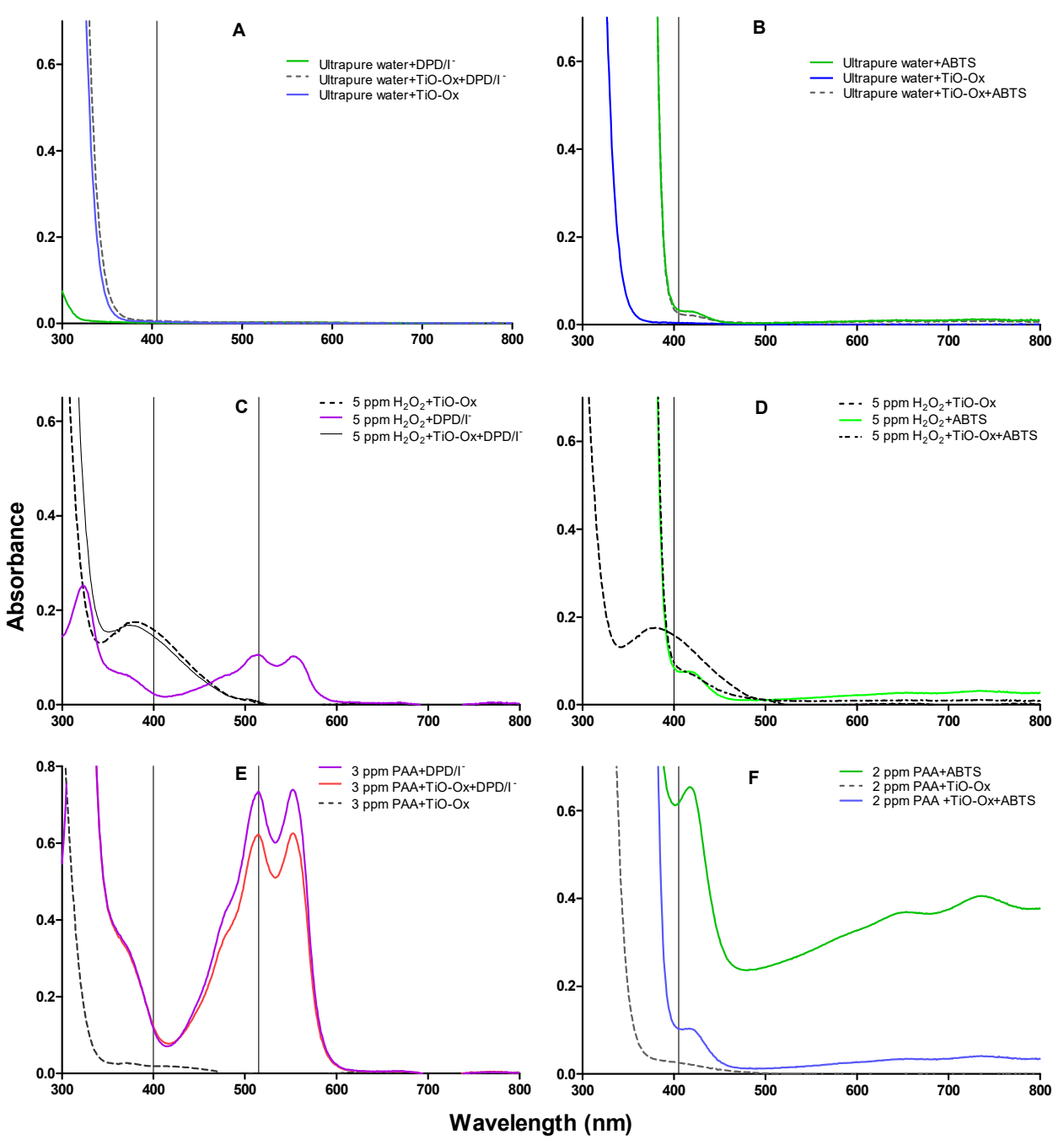

Figure 2. Absorption spectra of oxidized colorimetric reagents; (A) absorption spectra of $\mathrm{DPD} / \mathrm{I}^{-}$, $\left[\mathrm{TiO}-\mathrm{Ox} \cdot \mathrm{DPD} / \mathrm{I}^{-}\right]$and $\mathrm{TiO}-\mathrm{Ox}$ mixed in ultrapure water to measure reagents background color and cross reactivity between the reagents, (B) absorption spectra of ABTS, [TiO-Ox-ABTS] and TiO-Ox mixed in ultrapure water to measure reagents background color and cross reactivity between the reagents, (C) absorption spectra of DPD. ${ }^{+}$and [TiO-Ox $\cdot \mathrm{H}_{2} \mathrm{O}_{2}$ ] obtained by oxidation with $5 \mathrm{mg} \cdot \mathrm{L}^{-1} \mathrm{H}_{2} \mathrm{O}_{2}$, (D) absorption spectra of ABTS ${ }^{+}$, [TiO-Ox $\cdot \mathrm{H}_{2} \mathrm{O}_{2}$ ] and [TiO-Ox $\cdot$ ABTS $\cdot{ }^{+} \cdot \mathrm{H}_{2} \mathrm{O}_{2}$ ] obtained by oxidation with $5 \mathrm{mg} \cdot \mathrm{L}^{-1} \mathrm{H}_{2} \mathrm{O}_{2}$, (E) absorption spectra of DPD ${ }^{+}$, and [TiO-Ox. DPD. ${ }^{+}$.PAA] obtained by oxidation with $3 \mathrm{mg} \cdot \mathrm{L}^{-1}$ PAA. Spectra after color reaction with $3 \mathrm{mg} \cdot \mathrm{L}^{-1} \mathrm{PAA}, \mathrm{DPD} / \mathrm{I}^{-}$; PAA, TiO-Ox, DPD $/ \mathrm{I}^{-}$and PAA, TiO-Ox. All color reaction was maintained at $\mathrm{pH} 5$ in presence of $\mathrm{KI}\left(70 \mathrm{~g} \cdot \mathrm{L}^{-1}\right)$ and $(\mathbf{F})$ absorption spectra of $\mathrm{ABTS}^{+}{ }^{+}$, $\left.\mathrm{TiO}-\mathrm{Ox} \cdot \mathrm{PAA}\right]$ and $\left[\mathrm{TiO}-\mathrm{Ox} \cdot \mathrm{ABTS}^{+} \cdot \mathrm{PAA}\right]$ obtained by oxidation with $2 \mathrm{mg} \cdot \mathrm{L}^{-1} \mathrm{PAA}$. 
When $\mathrm{H}_{2} \mathrm{O}_{2}$ reacted with TiO-Ox, the yellow colored titanium peroxide complex was formed which can be measured spectrophotometrically at $400 \mathrm{~nm}$ (Figure 2C). Furthermore, when $\mathrm{H}_{2} \mathrm{O}_{2}$ reacted with DPD/ $/ \mathrm{I}^{-}$reagents buffered at $\mathrm{pH} 5$, the pink colored oxidized form of DPD ( $\mathrm{DPD}^{+}$) was formed (Figure 2C). The DPD ${ }^{+}$has an absorption peak at $515 \mathrm{~nm}$, which usually is used for quantification. However, when mixing the formed titanium peroxide complex with the $\mathrm{DPD} / \mathrm{I}^{-}$reagents at $\mathrm{pH} 5$, no peak was observed at $515 \mathrm{~nm}$ (Figure 2C). Thus, it was observed that complex formed from the reaction of TiO-Ox and $\mathrm{H}_{2} \mathrm{O}_{2}$ does not react with $\mathrm{DPD} / \mathrm{I}^{-}$. This makes combined colorimetric reaction of TiO-Ox and DPD/ $/ \mathrm{I}^{-}$selective to measure $\mathrm{H}_{2} \mathrm{O}_{2}$ and peroxycarboxylic acid simultaneously. Furthermore, no change in the absorption spectra was observed when the titanium peroxide complex was mixed with ABTS compared with the absorption spectra of $\mathrm{H}_{2} \mathrm{O}_{2}$ reacted with ABTS at $400 \mathrm{~nm}$ (Figure 2D). Moreover, the absorbance of TiO-Ox: $\mathrm{H}_{2} \mathrm{O}_{2}$ complex at $400 \mathrm{~nm}$ was higher than the absorbance of ABTS oxidized by $\mathrm{H}_{2} \mathrm{O}_{2}$ (Figure 2D) since TiO-Ox colorimetric assay was selective for $\mathrm{H}_{2} \mathrm{O}_{2}$.

\subsubsection{Peracetic Acid Reaction with TiO-Ox}

Commercial solutions of PAA contains different ratio of PAA: $\mathrm{H}_{2} \mathrm{O}_{2}$ in equilibrium. When TiO-Ox was mixed with $3 \mathrm{mg} \cdot \mathrm{L}^{-1}$ commercial PAA, it reacted with $\mathrm{H}_{2} \mathrm{O}_{2}$ that was present in the commercial PAA solution resulting in fainted yellow color and high absorbance at $400 \mathrm{~nm}$ (Figure 2E). To check the selective reaction of TiO-Ox and $\mathrm{H}_{2} \mathrm{O}_{2}$, absorbance recorded at $400 \mathrm{~nm}$ was converted to the $\mathrm{H}_{2} \mathrm{O}_{2}$ concentration using calibration curve and same concentration of $\mathrm{H}_{2} \mathrm{O}_{2}$ was spiked to ultrapure water and quantified using TiO-Ox reagents. Same absorbance at $400 \mathrm{~nm}$ was observed when $\mathrm{TiO}-\mathrm{Ox}$ was mixed with $3 \mathrm{mg} \cdot \mathrm{L}^{-1}$ commercial PAA in ultrapure water spiked with $\mathrm{H}_{2} \mathrm{O}_{2}$ solution (Figure $3 \mathrm{~A}$ ). Moreover, when 1, 2, 5 and $10 \mathrm{mg} \cdot \mathrm{L}^{-1} \mathrm{H}_{2} \mathrm{O}_{2}$ was spiked in $3 \mathrm{mg} \cdot \mathrm{L}^{-1}$ PAA and measured with TiO-Ox, the absorbance at $400 \mathrm{~nm}$ increased with increasing $\mathrm{H}_{2} \mathrm{O}_{2}$ concentration (Figure 3B). This shows TiO-Ox does not react with PAA but can selectively react with $\mathrm{H}_{2} \mathrm{O}_{2}$.

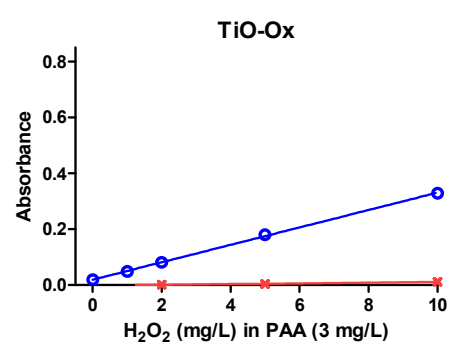

(A)

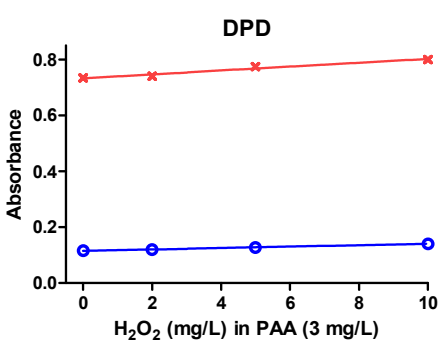

(B)

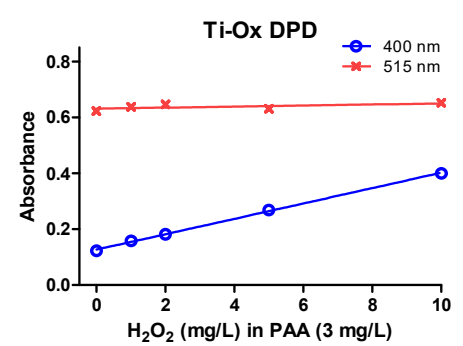

(C)

Figure 3. Absorbance of oxidized colorimetric reagents; absorbance of TiO-Ox obtained by oxidation with $0,1,2,5$ and $10 \mathrm{mg} \cdot \mathrm{L}^{-1} \mathrm{H}_{2} \mathrm{O}_{2}$ spiked in $3 \mathrm{mg} \cdot \mathrm{L}^{-1}$ PAA (A); absorbance of DPD ${ }^{\bullet+}$ obtained by oxidation with $0,1,2,5$ and $10 \mathrm{mg} \cdot \mathrm{L}^{-1} \mathrm{H}_{2} \mathrm{O}_{2}$ spiked in $3 \mathrm{mg} \cdot \mathrm{L}^{-1}$ PAA (B) and absorbance of TiO-Ox:DPD ${ }^{+}$obtained by oxidation with $0,1,2,5$ and $10 \mathrm{mg} \cdot \mathrm{L}^{-1} \mathrm{H}_{2} \mathrm{O}_{2}$ spiked in $3 \mathrm{mg} \cdot \mathrm{L}^{-1}$ PAA (C). Absorbance were recorded at $400 \mathrm{~nm}$ and $515 \mathrm{~nm}$. Error bars indicating standard deviation $(n=3)$ were always smaller than the symbol representing the averages.

\subsubsection{Peracetic Acid Reaction with $\mathrm{DPD} / \mathrm{I}^{-}$}

Experiments were performed to investigate whether PAA reacts with $\mathrm{DPD} / \mathrm{I}^{-}$buffered at $\mathrm{pH} 5$ with and without presence of TiO-Ox. The oxidation of colorless DPD to its pink product DPD. ${ }^{+}$by $3 \mathrm{mg} \cdot \mathrm{L}^{-1} \mathrm{PAA}$ at $\mathrm{pH} 5 \mathrm{in}$ presence of iodide was observed and the absorption spectrum from $300 \mathrm{~nm}$ to $800 \mathrm{~nm}$ was measured (Figure 2E). An absorbance peak was observed at $515 \mathrm{~nm}$ which usually is used for quantification of $\mathrm{DPD}^{+}$. In another experiment, TiO-Ox was added prior to $\mathrm{DPD} / \mathrm{I}^{-}$, to investigate the interference of TiO-Ox on oxidation of DPD by PAA. The absorption spectrum of DPD/ $/ \mathrm{I}^{-}$and PAA in presence of TiO-Ox showed that DPD was oxidized by PAA and pink color was developed (Figure 2E). However, less color development was observed since the $\mathrm{H}_{2} \mathrm{O}_{2}$ present in the PAA mixture 
reacted with TiO-Ox and not with DPD. A slight increase in absorbance at $400 \mathrm{~nm}$ was observed which was due to the reaction of TiO-Ox with $\mathrm{H}_{2} \mathrm{O}_{2}$.

The selectivity of the reaction was tested by measuring a $3 \mathrm{mg} \cdot \mathrm{L}^{-1}$ PAA sample spiked with 1, 2, 5 and $10 \mathrm{mg} \cdot \mathrm{L}^{-1} \mathrm{H}_{2} \mathrm{O}_{2}$ and absorbance was measured at $400 \mathrm{~nm}$ and $515 \mathrm{~nm}$ with TiO-Ox, $\mathrm{DPD} / \mathrm{I}^{-}$and TiO-Ox:DPD/ $/ \mathrm{I}^{-}$color assays. When TiO-Ox color assay was tested, absorbance at $400 \mathrm{~nm}$ increased with increasing concentration of $\mathrm{H}_{2} \mathrm{O}_{2}$ as mentioned in the Section 3.2.2 while absorbance at $515 \mathrm{~nm}$ was close to zero (Figure 3A). When $3 \mathrm{mg} \cdot \mathrm{L}^{-1}$ PAA spiked with $\mathrm{H}_{2} \mathrm{O}_{2}$ were quantified with $\mathrm{DPD} / \mathrm{I}^{-}$color assay, a small but fixed peak was observed at $400 \mathrm{~nm}$ with almost no effect of increasing $\mathrm{H}_{2} \mathrm{O}_{2}$ concentration while at $515 \mathrm{~nm}$ the absorbance increased with increasing concentration of $\mathrm{H}_{2} \mathrm{O}_{2}$ (Figure $3 \mathrm{~B}$ ). When $3 \mathrm{mg} \cdot \mathrm{L}^{-1}$ PAA spiked with $\mathrm{H}_{2} \mathrm{O}_{2}$ were quantified with TiO-Ox:DPD/ $/ \mathrm{I}^{-}$, the absorbance at $400 \mathrm{~nm}$ increased however, this was not the case at $515 \mathrm{~nm}$ (Figure 3C). The quantification of PAA was shown not to be biased by the presence of $\mathrm{H}_{2} \mathrm{O}_{2}$, as addition of $1,2,5$ and $10 \mathrm{mg} \cdot \mathrm{L}^{-1} \mathrm{H}_{2} \mathrm{O}_{2}$ in $3 \mathrm{mg} \cdot \mathrm{L}^{-1}$ PAA did not affect the absorbance at $515 \mathrm{~nm}\left(\mathrm{DPD}^{+}\right)$but resulted in increased absorption at $400 \mathrm{~nm}$ (titanium peroxide complex). Thus, when $\mathrm{H}_{2} \mathrm{O}_{2}$ reacts with TiO-Ox to form titanium peroxide complex, it will not react further with $\mathrm{DPD} / \mathrm{I}^{-}$color reagent under the given condition.

Therefore, it was shown that $\mathrm{DPD} / \mathrm{I}^{-}$for PAA quantification was not interfered by presence of TiO-Ox and TiO-Ox:DPD/ $/ \mathrm{I}^{-}$color assay can be used selectively to measure PAA and $\mathrm{H}_{2} \mathrm{O}_{2}$.

\subsubsection{Peracetic Acid Reaction with ABTS}

Colorless ABTS was oxidized to green colored ABTS. ${ }^{+}$by PAA at $\mathrm{pH} 3.5$ (Figure $2 \mathrm{~F}$ ) which was also observed in our previous study [11]. When three different concentration of PAA, $1 \mathrm{mg} \cdot \mathrm{L}^{-1}$, $3 \mathrm{mg} \cdot \mathrm{L}^{-1}$ and $5 \mathrm{mg} \cdot \mathrm{L}^{-1}$, was mixed with ABTS, absorbance at $405 \mathrm{~nm}$ increased gradually (see SI, Figure S1). An experiment was performed to investigate whether presence of $\mathrm{TiO}-\mathrm{Ox}$ interfere with the color development of ABTS when oxidized by PAA. Absorbance of ABTS. ${ }^{+}$at $405 \mathrm{~nm}$ was higher than the absorbance of ABTS. ${ }^{+}$in the presence of TiO-Ox and thus TiO-Ox interferes the reaction of ABTS with PAA. To eliminate the interference of TiO-Ox on ABTS quantification, the two-step quantification method was applied where absorbance of TiO-Ox and PAA was measured in one cuvette and absorbance of $\mathrm{ABTS}^{\bullet+}$ oxidized by PAA was measured in a second cuvette.

\subsection{Method Characterization}

Calibration curve was made for PAA and $\mathrm{H}_{2} \mathrm{O}_{2}$ using different concentration of oxidants by using DPD/I- $/ \mathrm{I}^{-}$ABTS, TiO-Ox and TiO-Ox:DPD/ $/ \mathrm{I}^{-}$colorimetric assay as described in Section 2.2 (Figure 4 and Table 1). LOD and LOQ for ABTS colorimetric assay for PAA was $0.0425 \mathrm{mg} \cdot \mathrm{L}^{-1}$ and $0.0500 \mathrm{mg} \cdot \mathrm{L}^{-1}$, respectively.

From the ABTS colorimetric assay direct measurement of PAA was done up to $30 \mathrm{mg} \cdot \mathrm{L}^{-1}$ with R-square 0.9993. LOQ and LOD for DPD/I- colorimetric assay for PAA was $0.0015 \mathrm{mg} \cdot \mathrm{L}^{-1}$ and $0.0025 \mathrm{mg} \cdot \mathrm{L}^{-1}$, respectively. Direct measurement of PAA was done up to $3 \mathrm{mg} \cdot \mathrm{L}^{-1}$ by using DPD/ $/ \mathrm{I}^{-}$ colorimetric assay with R-square 0.9944. LOQ and LOD for TiO-Ox:DPD/ $\mathrm{I}^{-}$colorimetric assay for PAA was $0.0024 \mathrm{mg} \cdot \mathrm{L}^{-1}$ and $0.0046 \mathrm{mg} \cdot \mathrm{L}^{-1}$, respectively. Direct measurement of PAA was done up to $2.5 \mathrm{mg} \cdot \mathrm{L}^{-1}$ by using TiO-Ox:DPD/I $\mathrm{I}^{-}$colorimetric assay with R-square 0.9976 . Moreover, a calibration curve of $\mathrm{H}_{2} \mathrm{O}_{2}$ was made from the absorbance recorded at $400 \mathrm{~nm}$ using TiO-Ox:DPD/ $/ \mathrm{I}^{-}$colorimetric assay when calibration curve was made for PAA. This was done by subtracting the absorbance of TiO-Ox:DPD. ${ }^{+}$with DPD. ${ }^{+}$at $400 \mathrm{~nm}$ and from this method direct measurement of $\mathrm{H}_{2} \mathrm{O}_{2}$ was done up to $5 \mathrm{mg} \cdot \mathrm{L}^{-1}$ with R-square 0.9948. LOD for TiO-Ox:DPD/ $/ \mathrm{I}^{-}$colorimetric assay for $\mathrm{H}_{2} \mathrm{O}_{2}$ was $0.0043 \mathrm{mg} \cdot \mathrm{L}^{-1}$ and $0.0091 \mathrm{mg} \cdot \mathrm{L}^{-1}$, respectively. Thus, TiO-Ox:DPD/I- colorimetric assay is suitable for the water industry that demands low concentration of disinfectant whilst ABTS colorimetric assay was suitable for the water industry that demand higher disinfectant dose. LOD and LOQ for TiO-Ox and $\mathrm{H}_{2} \mathrm{O}_{2}$ was $0.0080 \mathrm{mg} \cdot \mathrm{L}^{-1}$ and $0.0127 \mathrm{mg} \cdot \mathrm{L}^{-1}$, respectively. Direct measurement of $\mathrm{H}_{2} \mathrm{O}_{2}$ was done up to $75 \mathrm{mg} \cdot \mathrm{L}^{-1}$ with R-square 1.00 . 
Table 1. Limit of detection, limit of quantification and maximum linearity of $\mathrm{ABTS}, \mathrm{DPD} / \mathrm{I}^{-}$, TiO-Ox:DPD// ${ }^{-}$and TiO-Ox colorimetric assay.

\begin{tabular}{|c|c|c|c|c|c|}
\hline & $\begin{array}{l}\text { ABTS Assay } \\
\left(\mathrm{mg} \cdot \mathrm{L}^{-1}\right)\end{array}$ & $\begin{array}{c}\mathrm{DPD} / \mathrm{I}^{-} \text {Assay } \\
\left(\mathrm{mg} \cdot \mathrm{L}^{-1}\right)\end{array}$ & $\begin{array}{c}\text { TiO-Ox:DPD/I } \\
\text { Assay-PAA } \\
\left(\mathrm{mg} \cdot \mathrm{L}^{-1}\right)\end{array}$ & $\begin{array}{c}\text { TiO-Ox:DPD/I- } \\
\text { Assay- } \mathrm{H}_{2} \mathrm{O}_{2} \\
\left(\mathrm{mg} \cdot \mathrm{L}^{-1}\right)\end{array}$ & $\begin{array}{l}\text { TiO-Ox Assay } \\
\quad\left(\mathrm{mg} \cdot \mathrm{L}^{-1}\right)\end{array}$ \\
\hline LOD & 0.0425 & 0.0015 & 0.0024 & 0.0043 & 0.0080 \\
\hline LOQ & 0.0500 & 0.0025 & 0.0046 & 0.0091 & 0.0127 \\
\hline Maximum linearity & 30 & 3 & 2.5 & 5 & 75 \\
\hline
\end{tabular}
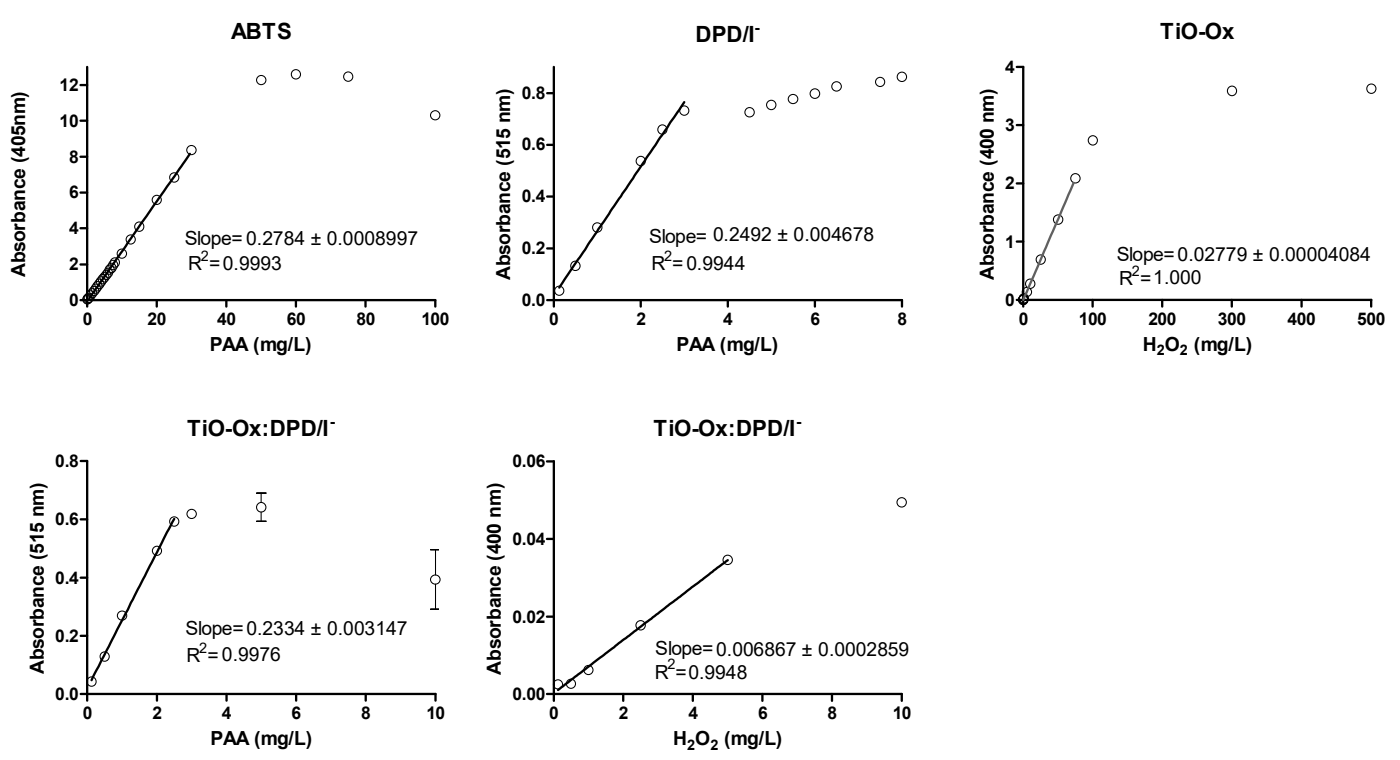

Figure 4. Calibration curve of PAA and $\mathrm{H}_{2} \mathrm{O}_{2}$ using ABTS, DPD/ $\mathrm{I}^{-}, \mathrm{TiO}-\mathrm{Ox}: \mathrm{DPD} / \mathrm{I}^{-}$and TiO-Ox as color reagents, respectively. Error bars indicating standard deviation $(n=3)$ are smaller than the symbol representing the averages for most concentrations. Note: different scales on the primary axes.

\subsection{Suitability of Colorimetric Assay for Different Samples}

The suitability of colorimetric assay in different samples with different water matrices were studied by measuring concentration profiles of PAA using DPD $/ \mathrm{I}^{-}$, TiO-Ox:DPD $/ \mathrm{I}^{-}$and $\mathrm{ABTS}$ color assay (Figures 5 and 6 ). DPD/I $\mathrm{I}^{-}$and TiO-Ox:DPD/ $\mathrm{I}^{-}$color assay was used to study the degradation of $2.6 \mathrm{mg} \cdot \mathrm{L}^{-1}$ PAA for 120 minutes in drinking water, sea water, lake water and wastewater effluent. Slow degradation of PAA was observed in lake water and sea water, while rapid degradation of PAA was observed in wastewater effluent and drinking water. The different degradation of PAA were due to the samples having different water matrices. The concentration of PAA quantified using DPD/I- $\mathrm{I}^{-}$and TiO-Ox:DPD/I- colorimetric assay was identical (Figure 5). Moreover, with TiO-Ox:DPD/I- colorimetric assay $\mathrm{H}_{2} \mathrm{O}_{2}$ was also quantification which is important when applying PAA for disinfection.

ABTS colorimetric assay was used to quantify $3 \mathrm{mg} \cdot \mathrm{L}^{-1}$ and $10 \mathrm{mg} \cdot \mathrm{L}^{-1}$ PAA in drinking water, sea water, lake water and wastewater for $60 \mathrm{~min}$ (Figure 6). Degradation of PAA in sea water and lake water were slow and similar to that was quantified using DPD $/ \mathrm{I}^{-}$and TiO-Ox:DPD/ $/ \mathrm{I}^{-}$color assay. Hence, ABTS and DPD/I- color assay can be used to quantify PAA and TiO-Ox:DPD/ $/ \mathrm{I}^{-}$color assay can be used to quantify PAA and $\mathrm{H}_{2} \mathrm{O}_{2}$ simultaneously in the samples with different characteristics. 


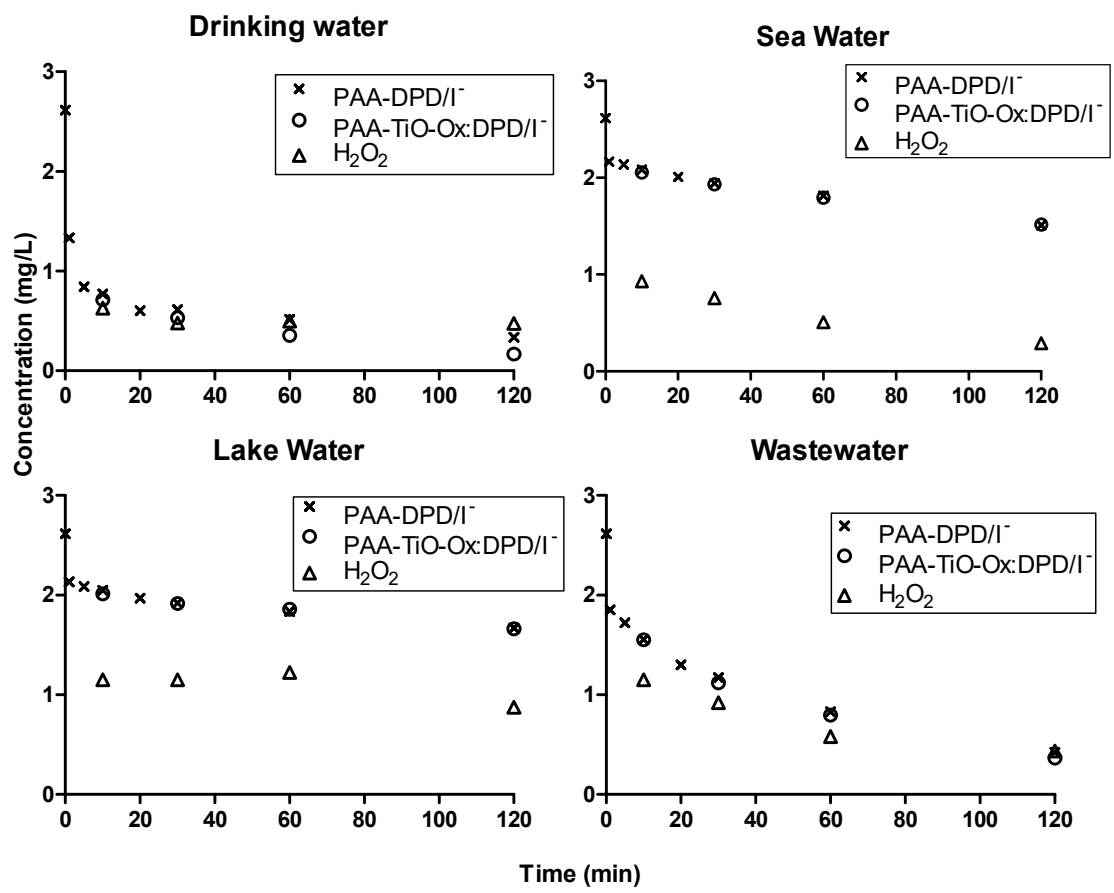

Figure 5. Concentration profiles of PAA and $\mathrm{H}_{2} \mathrm{O}_{2}$ in drinking water, sea water, lake water and wastewater effluent quantified using $\mathrm{DPD} / \mathrm{I}^{-}$and TiO-Ox:DPD/ $\mathrm{I}^{-}$colorimetric assay when spiked with $2.6 \mathrm{mg} \cdot \mathrm{L}^{-1} \mathrm{PAA}$.

Drinking water
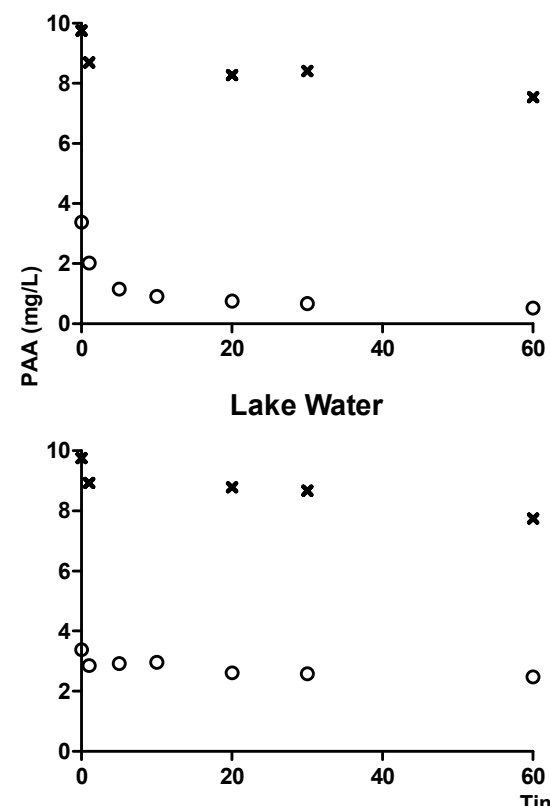

Sea Water
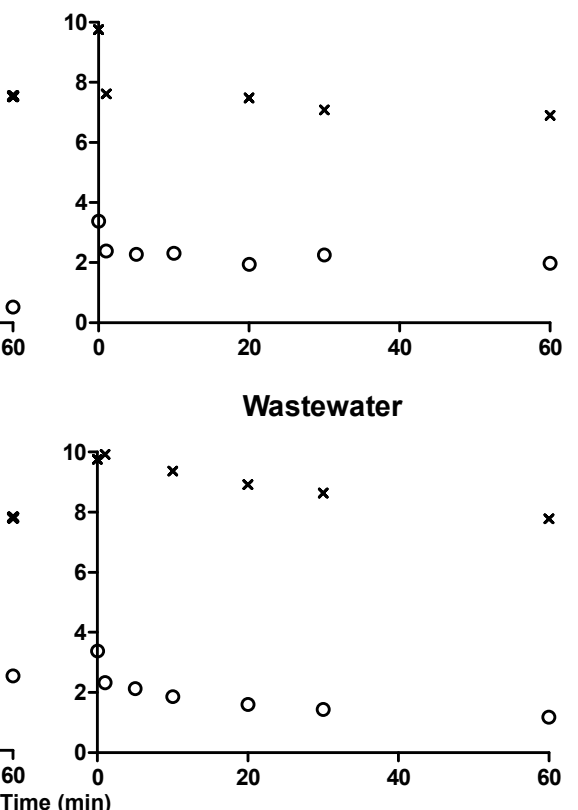

Figure 6. Concentration profiles of PAA in drinking water, seawater, lake water and wastewater quantified using ABTS colorimetric assay. ' $x$ ' symbol in the graphs represents the concentration profile of $10 \mathrm{mg} \cdot \mathrm{L}^{-1} \mathrm{PAA}$ and 'o' symbol in the graphs represents the concentration profile of $3 \mathrm{mg} \cdot \mathrm{L}^{-1} \mathrm{PAA}$.

\section{Conclusions}

An optimized combination of two colorimetric reactions are presented that allows simultaneous quantification of $\mathrm{H}_{2} \mathrm{O}_{2}$ and a peroxycarboxylic acid at the $\mathrm{mg} \cdot \mathrm{L}^{-1}$ level when it is applied in water for disinfection purposes. $\mathrm{H}_{2} \mathrm{O}_{2}$ was quantified by adding titanium oxide oxalate (TiO-Ox) followed 
by addition of $\mathrm{DPD} / \mathrm{I}^{-}$and allow color development so both concentrations could be determined simultaneously in one cuvette. In another combination of colorimetric reaction, $\mathrm{H}_{2} \mathrm{O}_{2}$ was quantified by TiO-Ox from the mixture of peroxycarboxylic acids in first step followed by quantification of peroxycarboxylic acids by addition of ABTS in second step in separate vials.

LOD and LOQ of optimized combination of two colorimetric reactions were measured followed by measuring maximum linear concentration of peroxycarboxylic acids and $\mathrm{H}_{2} \mathrm{O}_{2}$. LOD and LOQ of ABTS colorimetric assay was $42.5 \mu \mathrm{g} \cdot \mathrm{L}^{-1}$ and $50 \mu \mathrm{g} \cdot \mathrm{L}^{-1}$, DPD/ $/ \mathrm{I}^{-}$colorimetric assay was $1.5 \mu \mathrm{g} \cdot \mathrm{L}^{-1}$ and $2.5 \mu \mathrm{g} \cdot \mathrm{L}^{-1}$, TiO-Ox:DPD/ $/ \mathrm{I}^{-}$colorimetric assay was $2.4 \mu \mathrm{g} \cdot \mathrm{L}^{-1}$ and $4.6 \mu \mathrm{g} \cdot \mathrm{L}^{-1}$ and for titanium oxide oxalate colorimetric assay was $8.0 \mu \mathrm{g} \cdot \mathrm{L}^{-1}$ and $12.7 \mu \mathrm{g} \cdot \mathrm{L}^{-1}$, respectively. Direct measurement of PAA using ABTS was up to $30 \mathrm{mg} \cdot \mathrm{L}^{-1}$ for PAA, up to $3 \mathrm{mg} \cdot \mathrm{L}^{-1}$ PAA by using DPD/I- colorimetric assay and up to $2.5 \mathrm{mg} \cdot \mathrm{L}^{-1} \mathrm{PAA}$ and $5 \mathrm{mg} \cdot \mathrm{L}^{-1} \mathrm{H}_{2} \mathrm{O}_{2}$ by using TiO-Ox:DPD/ $/ \mathrm{I}^{-}$colorimetric assay. By using titanium oxide oxalate colorimetric assay $80 \mathrm{mg} \cdot \mathrm{L}^{-1}, \mathrm{H}_{2} \mathrm{O}_{2}$ was measured directly.

Suitability of the colorimetric method for PAA and $\mathrm{H}_{2} \mathrm{O}_{2}$ was tested by spiking peracetic acid to the water samples from typical applications; tap water, lake water, seawater, and biological treated municipal wastewater. The concentration of PAA and $\mathrm{H}_{2} \mathrm{O}_{2}$ were quantified over time by applying combination of two colorimetric assay; TiO-Ox:DPD/ $\mathrm{I}^{-}$and TiO-Ox:ABTS.

Supplementary Materials: The following are available online at http://www.mdpi.com/1660-4601/17/13/4656/s1, Figure S1: Absorption spectra of oxidized ABTS mixed with 1, 3 and $5 \mathrm{mg} \cdot \mathrm{L}-1$ PAA in ultrapure water (left), Absorption spectra of oxidized TiO-Ox mixed with 1, 3 and $5 \mathrm{mg} \cdot \mathrm{L}-1$ PAA in ultrapure water (right).

Author Contributions: Conceptualization, R.K.C. and H.R.A.; methodology, R.K.C. and H.R.A.; writing-original draft preparation, R.K.C. and H.R.A.; writing-review and editing, R.K.C., K.M.S.K. and H.R.A.; visualization, R.K.C.; supervision, H.R.A. All authors have read and agreed to the published version of the manuscript.

Funding: This research received no external funding.

Conflicts of Interest: The authors declare no conflict of interest.

\section{References}

1. White, G.C. Handbook of Chlorination and Alternative Disinfectants, 5th ed.; John Wiley \& Sons, Inc.: New York, NY, USA, 2010.

2. Veschetti, E.; Cittadini, B.; Maresca, D.; Citti, G.; Ottaviani, M. Inorganic by-products in waters disinfected with chlorine dioxide. Microchem. J. 2005, 79, 165-170. [CrossRef]

3. Watson, K.; Shaw, G.; Leusch, F.D.L.; Knight, N.L. Chlorine disinfection by-products in wastewater effluent: Bioassay-based assessment of toxicological impact. Water Res. 2012, 46, 6069-6083. [CrossRef]

4. Emmanuel, E.; Keck, G.; Blanchard, J.-M.; Vermande, P.; Perrodin, Y. Toxicological effects of disinfections using sodium hypochlorite on aquatic organisms and its contribution to AOX formation in hospital wastewater. Environ. Int. 2004, 30, 891-900. [CrossRef]

5. Hrudey, S.E.; Charrois, W.J. Disinfection By-Products and Human Health; IWA Publishing: London, UK, 2012; ISBN 9781843395195.

6. Nurizzo, C.; Antonelli, M.; Profaizer, M.; Romele, L. By-products in surface and reclaimed water disinfected with various agents. Desalination 2005, 176, 241-253. [CrossRef]

7. Svecevicius, G.; Šyvokiene, J.; Stasiunaite, P.; Mickeniene, L.; Syvokiene, J.; Stasiŭnaite, P. Acute and chronic toxicity of chlorine dioxide $(\mathrm{ClO} 2)$ and chlorite (ClO2-) to rainbow trout (Oncorhynchus mykiss). Environ. Sci. Pollut. Res. 2005, 12, 302-305. [CrossRef]

8. Boczek, L.A.; Johnson, C.H.; Meckes, M.C. Chlorine disinfection of blended municipal wastewater effluents. Water Environ. Res. 2010, 82, 2373-2379. [CrossRef] [PubMed]

9. Bayo, J.; Angosto, J.M.; Gómez-López, M.D. Ecotoxicological screening of reclaimed disinfected wastewater by Vibrio fischeri bioassay after a chlorination-dechlorination process. J. Hazard. Mater. 2009, 172, 166-171. [CrossRef] [PubMed]

10. Liberti, L.; Notarnicola, M. Advanced treatment and disinfection for municipal wastewater reuse in agriculture. Water Sci. Technol. 1999, 40, 235-245. [CrossRef] 
11. Chhetri, R.K.; Thornberg, D.; Berner, J.; Gramstad, R.; Ojstedt, U.; Sharma, A.K.; Andersen, H.R. Chemical disinfection of combined sewer overflow waters using performic acid or peracetic acids. Sci. Total Environ. 2014, 490, 1065-1072. [CrossRef] [PubMed]

12. Antonelli, M.; Rossi, S.; Mezzanotte, V.; Nurizzo, C. Secondary effluent disinfection: PAA long term efficiency. Environ. Sci. Technol. 2006, 40, 4771-4775. [CrossRef] [PubMed]

13. Falsanisi, D.; Gehr, R.; Santoro, D.; Dell'Erba, A.; Notarnicola, M.; Liberti, L.; Dell’Erba, A.; Notarnicola, M.; Liberti, L. Kinetics of PAA demand and its implications on disinfection of wastewaters. Water Qual. Res. J. Canada 2006, 41, 398-409. [CrossRef]

14. Kitis, M. Disinfection of wastewater with peracetic acid: A review. Environ. Int. 2004, 30, 47-55. [CrossRef]

15. Koivunen, J.; Heinonen-Tanski, H. Peracetic acid (PAA) disinfection of primary, secondary and tertiary treated municipal wastewaters. Water Res. 2005, 39, 4445-4453. [CrossRef]

16. Luukkonen, T.; Heyninck, T.; Rämö, J.; Lassi, U.; Ramo, J.; Lassi, U. Comparison of organic peracids in wastewater treatment: Disinfection, oxidation and corrosion. Water Res. 2015, 85, 275-285. [CrossRef] [PubMed]

17. Baldry, M.G.C. The bactericidal, fungicidal and sporicidal properties of hydrogen peroxide and peracetic acid. J. Appl. Bacteriol. 1983, 54, 417-423. [CrossRef]

18. Chhetri, R.K.; Bonnerup, A.; Andersen, H.R. Combined Sewer Overflow pretreatment with chemical coagulation and a particle settler for improved peracetic acid disinfection. J. Ind. Eng. Chem. 2016. [CrossRef]

19. Wagner, M.; Brumelis, D.; Gehr, R. Disinfection of Wastewater by Hydrogen Peroxide or Peracetic Acid: Development of Procedures for Measurement of Residual Disinfectant and Application to a Physicochemically Treated Municipal Effluent. Water Environ. Res. 2002, 74, 33-50. [CrossRef] [PubMed]

20. Pedersen, L.-F.; Pedersen, P.B.; Nielsen, J.L.; Nielsen, P.H. Peracetic acid degradation and effects on nitrification in recirculating aquaculture systems. Aquaculture 2009, 296, 246-254. [CrossRef]

21. Bader, H.; Sturzenegger, V.; Hoigné, J. Photometric method for the determination of low concentrations of hydrogen peroxide by the peroxidase catalyzed oxidation of N,N-diethyl-p-phenylenediamine (DPD). Water Res. 1988, 22, 1109-1115. [CrossRef]

22. Pinkernell, U.; Lüke, H.-J.; Karst, U. Selective photometric determination of peroxycarboxylic acids in the presence of hydrogen peroxide. Analyst 1997, 122, 567-571. [CrossRef]

23. Antoniou, M.G.; Andersen, H.R. Comparison of UVC/S2O82- with UVC/H2O2 in terms of efficiency and cost for the removal of micropollutants from groundwater. Chemosphere 2015, 119, S81-S88. [CrossRef] [PubMed]

24. Domínguez-Henao, L.; Turolla, A.; Monticelli, D.; Antonelli, M. Assessment of a colorimetric method for the measurement of low concentrations of peracetic acid and hydrogen peroxide in water. Talanta 2018, 183, 209-215. [CrossRef] [PubMed]

25. Gehr, R.; Chen, D.; Moreau, M. Performic acid (PFA): Tests on an advanced primary effluent show promising disinfection performance. Water Sci. Technol. 2009, 59, 89-96. [CrossRef] [PubMed]

(C) 2020 by the authors. Licensee MDPI, Basel, Switzerland. This article is an open access article distributed under the terms and conditions of the Creative Commons Attribution (CC BY) license (http://creativecommons.org/licenses/by/4.0/). 